\title{
THE LEGAL AUTHORITY OF THE JURIST AND ITS SCOPE IN MODERN IRAN ${ }^{1}$
}

\author{
Seyfeddin Kara ORCID ID: https://orcid.org/0000-0002-0651-0859 \\ Independent researcher \\ Email: skara@contemporarystudyofislam.org
}

Mohammad Saeed Bahmanpour ORCID ID: https://orcid.org/0000-0002-7695-3110
Independent researcher
Email: sbahmanpour@hotmail.com

\begin{abstract}
The development of Shi'i jurisprudence has mostly been studied from the perspective of its relation to political authority. A handful of works that have examined the subject from a purely legal perspective neglected the influence of Muslim societies on the evolution of Shi'i legal theory. The paper examines the development of Shi' $i$ jurisprudence from a legal perspective and argues that there is an intrinsic connection between Islamic law (both Sunni and Shi'i laws) and Muslim societies. Therefore, the changing values and expectations of society prompt changes in Islamic rulings. In this sense, the evolution of Shi'i legal theory is no different to Sunni legal theory, and there are striking similarities between Khomeini's theory of wilāyat al-faqīh and the Sunni legal notion of mașlaha which both aim to respond to the exigencies of social change.
\end{abstract}

\section{INTRODUCTION}

The development of Shici jurisprudence has mostly been studied from the perspective of its relation to a political authority, either that of the Shici jurists or their attitude towards existing rulers' authority. The main reason for this approach is perhaps the triumph of the Islamic revolution in 1979. The amount of work done in the field of Shici studies was limited until the Revolution, after which volumes of studies have been undertaken in an attempt to understand how an '8o-year-old Ayatollah [...] who lived on garlic and onions and yoghurt'2 managed to bring down one of the most powerful regimes in the Middle East. Due to their point of departure, these studies focused on the roots and the legitimacy of the newly formed Islamic Republic and its system: the theory of wilayat al-faqì (Persian: vilāyat-i faqìh, guardianship of the jurist). Consequently, these works were concerned with 
investigating the origins of the theory within Shici political and legal theories. Understandably, these studies are mostly centred on the political aspect of the theory of wiläyat al-faqih , which was fashioned by the enigmatic leader of the Islamic revolution, Ayatollah Ruhollah Musavi Khomeini. ${ }^{3}$

Although wilayat al-faqì was an old and widely held theory among Shici jurists, its implementation in the Islamic Republic of Iran and scope added to it by Khomeini presented a new and complicated system which was difficult to understand even for many Shici scholars. The theory advocates the establishment of an 'Islamic government' with absolute authority to execute Islamic law in response to the needs of the society. Based on this crude definition, the concept consists of two components: politics and jurisprudence. However, since the political significance of the concept is perceived as more pressing than its jurisprudential aspect, the concept has, by and large, been studied from the perspective of political theory. The obvious aim of such an approach is to understand the roots and legitimacy of the newly formed Islamic Republic, thus leaving the jurisprudential significance of the concept mostly ignored.

In this regard, the overemphasis of studies concerning the theory of wilayat al-faqih on ideology and politics has precluded many scholars from understanding the jurisprudential aspect of the concept and from gaining a deeper understanding of the development of Shic $i$ legal theory. As a result, current developments pertaining to Iranian/Shici law have been largely misunderstood and misinterpreted. Thus, this article aims to explore how Shici jurisprudence has evolved over the course of history and remained relevant in the face of ever-changing social values and structures. We will also scrutinise some of the misconceptions pertaining to Shici legal theory and the theory of wilayat al-faqìh, to initiate a fresh and a long overdue debate on the subject.

The concept of wiläyat al-faqih is understood as an evolution of Shici jurisprudence which has filled an important gap by providing a reconciliation between Islamic law and the changing structure of society through granting absolute authority to the Supreme Jurist to override explicit rules of Islamic law, based on the notion of the necessities of time and place. Consequently, we argue that there is a profound connection between Islamic law and social exigencies; even in different legal schools, similar exigencies give rise to similar solutions. In this regard, it is demonstrated that not only are there striking similarities between Khomeini's version of wilayyat al-faqih and the Sunni legal notion of mașlaha, but also that the former provides a procedure for the orderly and methodical implementation of the latter.

This article will first look at the relationship between Islamic law and the exigencies of time and place. Upon noting the similarities between Shici and Sunni legal theories in their responses to the challenges of modernity, we turn to the concept of wilayat al-faqih in the history of Shici jurisprudence and examine how, within this framework, the changing exigencies of modern Iranian society have led to a drastic revision of Islamic law. The final section provides scrutiny of some of the current criticisms of the theory of wilayat al-faqih from a legal perspective. 


\section{PREVIOUS STUDIES ON SHI'I LEGAL THEORY IN WESTERN ACADEMIA}

There are, indeed, some exceptions to the study of Shici jurisprudence from an exclusively political perspective, and we will briefly mention some of the most notable ones in the following. Perhaps one of the most comprehensive works on Shici legal theory, to the present day, was undertaken by Norman Calder in his $\mathrm{PhD}$ thesis entitled 'The Structure of Authority in Imami Shi'i Jurisprudence,' ${ }^{4}$ submitted in 1980. The theoretical framework of the research is clearly under the influence of Joseph Schacht and John Wansbrough and thus presents a partial understanding of Islamic law and Muslim jurists. ${ }^{5}$ Nevertheless, Calder provides a notable study of the major Shici sources in his quest to locate the structure of authority in Imami (Twelver) Shici jurisprudence. ${ }^{6}$ In 1981, Ann K. S. Lambton published her State and Government in Medieval Islam: An Introduction to the Study of Islamic Political Theory: The Furists, ${ }^{7}$ which also includes a great deal of discussion on Shici legal theory with a specific focus on authority. There are striking similarities between the two studies, although Lambton's work was published two years after the Islamic revolution and therefore, unlike Calder, her attention is turned mostly to political authority. The similarity between the two may be explained by the fact that Lambton was Calder's PhD supervisor and therefore influenced him.

Hossein Modarressi's An Introduction to Shi'i Law: A Bibliographical Study can be cited as another important work on the subject, in that he provides a succinct and astute contribution toward understanding the development of Shici jurisprudence. His focus is neither on religious authority nor political authority; instead, Modarressi provides an accurate study of the historical evolution of Shic $i$ jurisprudence and challenges some of the misconceptions attributed to it. However, he seldom mentions the current state of Shici jurisprudence and does not deal with the theory of wilāyat al-faqīh. ${ }^{8}$

Said Amir Arjomand in his detailed and wide-ranging study The Shadow of God and the Hidden Imam $^{9}$ studies the development of Shici legal system, with an emphasis on the relation between the state and Shici jurists. His analysis ranges from the origins of Shicism until 1980, and similar to Hamid Algar, ${ }^{10}$ argues that Shici jurists only emerged as a group that is independent of the state during the Qajar Dynasty. ${ }^{11} \mathrm{He}$ further argues that with the dominance of the Usuli movement, the authority of the Shici jurist expanded greatly. The Usuli scholars, upon defeating their Akhbari opponents and consequently establishing the practice of ijtihad as a norm, then claimed al-niyāba al- ${ }^{`} \bar{a} m m a$ (general deputyship) of the Twelfth Imam. ${ }^{12}$ However, as we will see in the following, such a conclusion is a result of the confusion of the concepts of niyāba or deputyship and wilāya or authority. Abdulaziz Sachedina in his important work The fust Ruler ${ }^{13}$ provides a historical analysis of the subject mostly from the perspective of political authority. Although it provides very useful information regarding the origins of the authority, the work does not discuss the modern period in detail.

Andrew Newman's PhD thesis ${ }^{14}$ presents an alternative theory regarding the development of Shici jurisprudence and argues that the conflict between the two Twelver Shici legal schools, rationalist (Usuli) and traditionalist (Akhbari), influenced the development of Shici legal theory. Finally, Devin J. Stewart's Islamic Legal Orthodoxy ${ }^{15}$ provides an impressive study of the development of Shici legal theory and presents his thesis that, by and large, 
the development of the Sunni legal theory and Shici scholars' concern to keep up with it were the main factors that contributed to the 'success and strength' of the Twelver Shici legal school. ${ }^{16} \mathrm{He}$ further argues that some of the leading Shici scholars were keen to be included in the consensus within the Sunni legal schools; thus, they did not hesitate to adopt Sunni legal methodologies into the Twelver Shici legal school. Stewart's work, to a certain extent, presents a good case for his thesis, but its main flaw is to single out the Twelver Shici legal school's competition with the Sunni legal schools as the driving force behind the development of Twelver legal theory. It is undeniable that in certain instances the influence of Sunni legal schools is noticeable on the Twelver legal theory; however, it is not the only factor for its development. Such an approach isolates the law from society, presents it as a field that only jurists have influence over, and implies that society has no input in shaping the laws. Consequently, the same criticism may be extended to Newman's study as he singles out the conflict between the rationalist and traditionalist legal schools.

Shahrough Akhavi's 'Contending discourses in Shici law on the doctrine of Wilayat Al-faqih' is a notable attempt to explain the origins of wilayat al-faqih and present debates on the legitimacy of the concept, however, the political focus of the work is noticeable. ${ }^{17}$ Finally, in his recent work, Hamid Mavani in his 'Ayatullah Khomeini's Concept of Governance (wilayat al-faqih) and the Classical Shi'i Doctrine of Imamate' makes a passionate effort against wilayat al-faqih within the context of recent political developments in Iran. ${ }^{18}$ Mavani's work also presents some prominent contemporary Shi'i scholars' opinions against wilāyat al-faqìh.

\section{THE CHALLENGE OF RECONCILIATION: ISLAMIC LAW AND THE EXIGENCIES OF TIME AND PLACE}

Like any other jurisprudential system, Islamic law is expected to deal with the needs of the society that it appeals to. As opposed to Muslim conservatism, which considered the elaboration of law 'a process of scholastic endeavour completely independent of historical or sociological influences, ${ }^{19}$ in Islam there is a deep and complex bond between the law and the exigencies of the society. However, in the same vein, the secular worldview, by and large, has perceived Islamic law as an instrument of religious suppression that imposes regressive rules on people. Consequently, both Muslim conservatism and the secular worldview fail to note the simple fact that, in the long run, a value or legal system can only survive if it appeals to the needs of society and forms an uninterrupted connection with it. ${ }^{20}$ The evolution of legal schools demonstrates that, based on the social environment, Muslim jurists can take drastically different approaches to the selection of legal sources and the implementation of Islamic law. ${ }^{21}$

Society is not a static institution but rather is constantly progressing in tune with ever-changing human needs. Throughout history, the speed of change has not been balanced, and Muslim societies, thanks to the emergence of a new religion and early Muslim conquests, have been exposed to rapid changes. Once a very dormant society, when the people of the Arabian Peninsula embraced the new religion, they were overwhelmed with a plethora of social, political, and economic changes. The early Muslims considered Islam 
a belief system which encompassed every aspect of their lives and hence expected Islam to address the effects of these rapid changes. This expectation then gave rise to the emergence of Islamic law as a separate field of expertise.

Islamic legal theory had surfaced in rudimentary form by the end of the second century $\mathrm{AH}$, and reached its maturity by the beginning of the fourth century AH. ${ }^{22}$ Based on their established legal theories, Muslim legal schools presented rulings for almost everything relevant to the society of the time. Once the 'revolutionary dust' ${ }^{23}$ of Islam settled, Muslim society yet again became dormant. Since there was no demand from the society, Muslim jurists restricted themselves to the status quo; instead of presenting new and independent legal rulings, they settled to become mujtahid fi al-madhab (mujtahid ${ }^{24}$ in the legal school). For a long time, the stagnation of Islamic law was mistakenly perceived as the closure of the gates of ijtihad and was pointed out as the root cause for the decline of Muslim civilisation. ${ }^{25}$

Bernard Weiss and then James Piscatori were some of the earliest scholars to argue against the idea of the closure of the gates of ijtihad. ${ }^{26}$ Wael B. Hallaq, in his well-known paper entitled 'Was the Gate of Ijtihad Closed?', provides an excellent overview of the ijtihad activities of Muslim jurists from $300 \mathrm{AH}$ onwards to make a strong case that Muslim jurists continued to issue fatwas throughout history and, contrary to popular assumption, the gates of ijtihad were never closed. ${ }^{27}$ Hallaq's study shows that when there was a need for the jurists to address a new situation, they fulfilled their 'collective duties' (fard al-kifāya). In order to verify his point, Hallaq draws attention to a period in which Abbasid caliphs were forced to share their authority with external political powers. ${ }^{28}$

The eighteenth century saw a great deal of change in Muslim societies. Thanks to the Industrial Revolution, European powers managed to amass unmatched strength and power and undertook a massive expansion and colonising campaign, including on the Muslim East. Once again Muslim jurists were called upon to address the newly emerging social changes for the faithful Muslims. ${ }^{29}$ However, the situation was more complex and demanding this time. The Industrial Revolution was a major turning point in history and led to colossal changes in all aspects of Muslim societies. These sweeping changes caused extreme difficulties for Muslim jurists, who wanted to reconcile the needs of society with preordained and 'fixed' divine laws. ${ }^{30}$ Both Sunni and Shi ${ }^{i}$ jurists dealt with this apparent dichotomy by attempting to reconcile Islamic law with the changing structures of society. Consequently, Muslim jurists' main focus has been a reconciliation project, especially over the last two centuries during which a surge of drastic changes swept the very foundation of Muslim societies.

As noted by Piscatori, Islam contains an element of flexibility and pragmatism that 'runs through the heart of Islam, ${ }^{31}$ and Muslim scholars who had the same understanding were set to face towering new challenges. In this regard, some Sunni jurists made use of the internal dynamics of Islamic law in order to combine it with Western legal systems. The first notable attempt came from the renowned Ottoman jurist Ahmed Cevded Pasha (d. 1895). He led a commission that codified Islamic law under the title Mecelle-i Ahkäm-i Adliye. The Mecelle was a code of law (qānün) in response to the secular camp within the ailing Ottoman Empire who maintained that newly established Western-style Nizamiye courts needed to jettison Islamic law and embrace the secular law inspired by the French legal system. ${ }^{32}$ The Mecelle resolved the apparent contradiction between the changing exigencies of the society 
and 'fixed' divine laws through a de facto dividing of Islamic law into two distinct parts: expressed rulings and unexpressed rulings. It states that the instances of Islamic rulings that are supported by decisive evidence from the Qur'an and sunna cannot be changed. Article 14 of the Mecelle outlines the fixed instances of the Islamic law by stating that it is not permitted [for jurists] to legislate new rulings, where there is a decisive text' ${ }^{33}$ However, based on the exigencies of the time, the instances of Islamic law that are not supported by evidence from the Qur'an and sunna may change. Article 39 of the Mecelle then states that 'it is undeniable that, with a change of times, the law changes' ${ }^{34}$

Another noteworthy attempt from Sunni scholars to address society's ever-changing needs came from Muhammad Rashid Rida. He was born in 1865 in Ottoman Syria and died in 1935 in Egypt, which was at the time a British protectorate. Rashid Rida seems to further develop what was expressed in the Mecelle in order to respond to the exigencies of the time. Enayat states that Rashid Rida believed that 'the essence of these rules [Islamic law] is their adaptability to meet the exigencies of every time and place, and fit the religious and political characteristics of every nation. The final criterion, however, against which such law should be judged remains the Sharī ${ }^{\complement} a h .{ }^{35}$ Rida states that:

relations governed by such rules are only subject to certain general religious principles, such as the individual's respect for one another's rights, honour, lives and properties. But outside of this provision, all administrative, judicial, political and military acts, in which the main intention is not 'nearness to God', belong to the 'branches' (furū') of the Sharī'ah, provided they are performed in good faith. This means that they are fit to be the subject of novel, man-made laws. ${ }^{36}$

For Rida, the principle of necessity warrants such a differentiation. ${ }^{37}$ Rida was, in fact, reiterating the views of his mentor, Muhammad 'Abduh (d. 1905), who was a very influential Egyptian thinker, activist, and jurist. However, whereas 'Abduh believed that rulings which have religious importance included in the sections of Islamic law on both 'ibādāt (worship) and $m u^{\prime} \bar{a}$ malāt (rules of general welfare) should remain untouched, Rida maintained that rulings regarding anything other than 'ibādatt (worship) may be changed based on human exigencies. ${ }^{38}$ What ${ }^{c}$ Abduh and Rida refer to is, in fact, the concept of mașlaha. The concept has been at the disposal of Sunni jurists since Hanafi jurist Abu Bakr al-Jassas (d. 370/980), but it was Shafici jurist Abu Hamid Muhammad al-Ghazali (d. 505/1111) who 'defined the mașlaha in a palpable manner.'39

The situation was not different for the Shici world; Shi'i scholars, in accordance with the expectations of society, tried to address the newly arising situations based on the exigencies of the society. It is commonly believed that Shici jurisprudence developed much later than the Sunni legal schools. Until the beginning of the minor occultation in $260 / 874$, Shic is did not feel there was a need to develop a jurisprudential system. Due to the presence of the infallible Imams, Shic is were able to put their legal questions to the Imams directly. ${ }^{40}$ Jurisprudential activities regained momentum towards the end of the minor occultation in 329/941. With the beginning of the major occultation, Shici jurists needed to advance their legal theory to adapt to a more challenging environment wherein the Imams were no longer present; this was aided by the emergence of a Shici-friendly state such as the Buwayhid 
Dynasty. ${ }^{41}$ The rise of Buwayhid rule (934-1062) in Iraq and Iran led to an environment ${ }^{42}$ wherein Shici religious rituals, doctrines and practices more freely entered the public sphere. ${ }^{43}$ In such a stimulating environment, some of the most prominent Twelver scholars and jurists such as Shaykh al-Mufid (d. 413/1022), al-Sharif al-Murtada (d. 436/1044), Shaykh al-Tusi (d. 460/1068), and al-Najashi (d. after 463/1071) responded to the needs of the Shici community and laid the foundation of Shici jurisprudence. ${ }^{44}$ After the fourth/tenth century until the Mongol invasion, in general, no significant challenges and developments affected Shi'i society and thus, like the Sunni world, social stagnation brought about a temporary jurisprudential stagnation. As far as Twelver Shicism is concerned, this was mainly due to the fall of the Buwayhids and the rise of the Seljuk Empire that was a champion of Sunni Islam. ${ }^{45}$

However, the Mongol invasion in the thirteenth century briefly changed the situation by shifting the balance of power in the religious landscape of most of the Muslim world. The Mongol and Ilkhanid periods yet again provided a suitable environment for Twelver Shicis, thanks to religious toleration of the Mongol rulers and support of some of the pro-Shici Ilkhanid rulers such as Ghazan (1295-1304 and his successor Öljeitu (1304-1316). During this period, the Twelver center of Hilla gave rise to the two prominent scholars: Najm al-Din al-Ja'far al-Hilli (d. 676/1276-7), known as Muhaqqiq al-Hilli, and his nephew Ibn al-Mutahhar al-Hilli (726/1325-6) known as 'Allama al-Hilli. Muhaqqiq al-Hilli is known to be the first Shici jurist who adopted ijtihad on a doctrinal basis. ${ }^{46}$ Further, more relevant to our study is that 'he linked the authority of 'ulamā directly to that of the Imam by making them his deputies (in a specific sense) during the Occultation. While the Imam appears to be present in the language of the previous Imami authors (such as Mufid and Tusi), the creation of this link may be considered a major step in the development of juristic authority. ${ }^{47}$ 'Allama al-Hilli further developed his uncle's work ${ }^{48}$ and produced some of the most influential works on Twelver Shici legal traditions received patronage from Ilkhanid rulers. ${ }^{49}$ Both jurists believed in the notion that jurists were the deputies of the Imam during his absence. ${ }^{50}$

However, this situation changed in the tenth/sixteenth century when the Safavids decided to convert to Shi ism and make it the official religion of the Safavid Dynasty. The Safavids invited Shici scholars from Lebanon and Bahrain to spread Shicism in Iran. This was a very stimulating environment for the scholars as they were also given the responsibility to administer Islamic law in the Safavid dynasty. Ann Lambton states that, during the Safavid period, a tendency to consider 'the fuqahā collectively as the deputy or $n \bar{a}$ ' $i b^{\text {' }} \bar{a} m m$ of the imām became stronger and more clearly expressed. ${ }^{51}$ She notes that this might have been a reaction from the ranks of the fuqah $\bar{a}^{2}$ (jurists) against the tendency to exalt the status of the shah..$^{52}$ However, it may also be argued that the demands of the circumstances in which

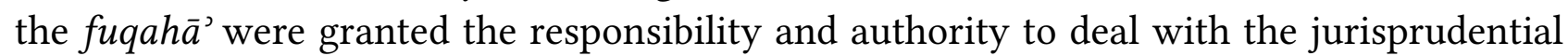
matters of the state urged the fuqah $\bar{a}^{3}$ to take a more practical position. Although, theoretically, Shici jurists believed in the authority and deputyship of the faqì practice played such a central role in the state, and thus, under Safavid rule, they suddenly found themselves facing the matters of everyday life. ${ }^{53}$ This prompted Shic $i$ jurists to effectively empower themselves with the deputyship of the Imam. Such a course of action was necessary as the Twelfth Imam played a very crucial role in Shici jurisprudence and, during 
the Imam's absence and under hostile circumstances, various aspects of Islamic law such as the Friday prayer and hudūd (sing. hadd, fixed penalties in Islamic law), were put on hold. One of the starkest examples of Shici jurists' practical empowerment can be seen in Shaykh 'Ali al-Karaki's (d. 940/1534) decree on Friday prayers. Al-Karaki, who was one of the most eminent Shici scholars of the Safavid era, believed that Muslims must observe the Friday prayer ${ }^{54}$ during the absence of the Imam; thus, he made the Friday prayers obligatory ${ }^{55}$ But al-Karaki's opinion was not unanimously endorsed by Shici scholars; Ibrahim Qatifi (1543), a 'rival and enemy'56 of al-Karaki, opined against the legitimacy of Friday prayers during the occultation. ${ }^{57}$ Lambton, who seems not to have grasped the fact that the dispute is much older than al-Karaki, assumes that al-Karaki regarded himself as the häkim al-shar' 'and consequently claimed that he had the authority to establish the Friday prayer and other similar rulings on behalf of the Imam. ${ }^{58}$

During the Safavid period, Shi $i$ scholars like al-Karaki gained great respect and authority due to their ability to form stable relations with society and state. They had a symbiotic relationship with the Safavid dynasty, but they also responded well to the needs of the society that underwent a drastic socio-religious transformation. The reason they managed the situation well was that they took a practical approach to Islamic law and realised the necessity of claiming the full authority (wilāya) of the Imam in jurisprudential affairs to overcome difficulties ${ }^{59}$ In this regard, some late sources mention that even Safavid rulers considered Shi' $i$ jurists 'as the $n \bar{a}{ }^{\prime} i b$ (representatives) of the imām in shar ${ }^{c} \bar{l}$ (legal) matters. ${ }^{60}$ Lambton, in this regard, notes the account of Muhammad Baqir Khwansari from his work Rawdat al-fannat:

When al-Karakī came to Iṣfahān and Qazwīn, Ṭahmāsp invested him with power and authority and said to him, 'You are more entitled to kingship [than I] because you are the $n \bar{a}$ 'ib of the imām. I am only one of your officials ('ummāl) and I (merely) carry out your commands and prohibitions.' Khawānsārī further asserts that Shāh Ṭahmāsp placed the affairs of the kingdom in the hands of al-Karaki and wrote a raqam to all the regions (buldān) ordering obedience to whatever the shaykh al-isläm commanded stating that the essence of kingship (așl al-mulk) belonged to him only, for he was the $n \bar{a} \mathfrak{i} i b$ of the $i m \bar{a} m$. He issued for him a farmān [decree] in which al-Karakî is called nă’ib-i imām and hujjat-i islām. In it, he is given the title of shaykh al-islām and all the officials of the diwān and the court are ordered to obey him. ${ }^{61}$

Lambton then speculates that although al-Karaki was highly regarded among Safavid rulers and exerted considerable influence in the Safavid courts, there was a possibility that Khwansari was trying to implement his own agenda as he 'was influenced by a desire to reinforce the position of mujtahids as the 'successors' of the imām, a position which they were openly claiming in the nineteenth century, and so attributed these words to Tahmasp with the deliberate intention of strengthening this claim. ${ }^{62}$ This speculation is based on the fact that Khwansari was a late source as he wrote the book in 1286/1869-70. However, what Lambton fails to consider is the historical background of the position of mujtahid as the $n \bar{a} i b$ of the Imam and that it was not a concept created through al-Karaki's relation with Tahmasp or some individuals trying to strengthen their own positions. Similarly, Calder expresses his suspicion about the authenticity of Tahmasp's statement about al-Karaki on 
the grounds that the style and content of the letter, according to him, give the impression that it belongs to a later generation, and thus had been fabricated. Calder's evidence is that it is unlikely that Tahmasp considered himself an ' $\bar{a} m i l$ (singular of 'ummāl) or an official of al-Karaki. ${ }^{63}$ But he does not take into consideration the practice of $t a^{c} \bar{a} r u f^{64}$ (etiquette), a very important characteristic of Persian culture. It is probable that Tahmasp dictated those words ${ }^{65}$ in the letter, but both al-Karaki and Tahmasp knew that he did not mean to be an 'official' of al-Karaki. Tahmasp was the ruler of Iran and it would be highly unrealistic to assume that he would want to share his political authority with al-Karakī. He was also aware that al-Karaki was never interested in political authority. Therefore, it could be that Tahmasp was rather exaggeratingly polite in expressing his respect for al-Karaki.

Nevertheless, Lambton acknowledges the existence of an original piece of historical evidence that is held in Tehran University. The evidence is in the form of a farma $\bar{a} n^{66}$ issued by Tahmasp that refers to al-Karaki as the $n \bar{a}$ ib al-imām (representative of the Imam).$^{67}$ In the face of the existence of historical evidence, ${ }^{68}$ Lambton and Calder's argument remains speculative, and this approach to the scholarship of 'the other', without enough investigation into their culture and history, has caused major flaws in their analysis. However, even if they are correct, Khawānsārī trying to 'strengthen' his claim to the deputyship of the Imam indicates that Shici scholars in the nineteenth century considered themselves the deputies of the Imam.

\section{THE PLACE OF WILĀYAT AL-FAQİH IN SHI'I LEGAL THEORY}

Before proceeding to discuss the place of wiläyat al-faqih, it is essential to distinguish two concepts which are usually confused in such discussions including that of Lambton. One is the concept of niyāba or deputyship and the other is the concept of wilàya or authority. There has been little dispute among Usuli Shi'i scholars that the fuqaha $\bar{a}^{\prime}$ are the general or unspecified deputies of the Twelfth Imam. The dispute, however, has been about the extent of their authority. In other words, wilāyat al-faqì is a unanimously accepted concept among Shi'i jurists while opinions dramatically differ regarding the extent of their wiläya or authority. ${ }^{69}$

As a class of people, the fuqah $\bar{a}^{3}$ have been regarded as the non-specific deputies of the absent Imam, called al-niyāba al-' ${ }^{\complement} \bar{m} m m a$ or general deputyship, as opposed to al-niyāba al-khāșșa $a^{70}$ or personal deputyship where the Imam appoints a specific person as his deputy. For both these deputies, some area of authority may be defined. For example, a person may be appointed by the Imam only to collect the khums (lit. one-fifth of gain) or to act as a judge in which case his wilayya or authority is limited to that particular area and he is said to have al-wilāya al-khāșsa. In cases where the extent of authority is not restricted, the deputy would have al-wilāya al- 'àmma or al-muțlaqa.

Of course, during the occultation, al-niyāba al-khāșsa is inconceivable for the jurists. However, as mentioned before, there is no dispute among the ușūli scholars that the faqīh has al-niyāba al-' $\bar{a} m m a$ at least in certain areas like issuing fatwas or looking after matters falling under the category of hisba or social necessities. In other words, there is no dispute that the $f a q i h$, as the general or unspecified deputy of the Imam, ${ }^{71}$ has been granted limited 
authority or al-wilāyat al-khāșsa according to narrations accepted by Usuli jurists. What has been disputed is the claim of certain early and later jurists regarding al-wilaya al-mutlaqa or al-'āmma.

Shaykh Muhammad Hasan al-Najafi (d. 1266/1849), whose work is regarded to have set the pace for contemporary Shici jurisprudential discourse, was a staunch advocate of al-wilaya al-mutlaqa or the all-encompassing authority of the jurist. He holds that the concept is a subject of consensus among Shici jurists and questions whether what is reported from scholars like Ibn Zuhra and Ibn Idris in opposition to al-wilaya al-muțlaqa is really a correct interpretation of their views. ${ }^{72}$ In his magnum opus, Jawahir al-Kalam fi Sharh Shara ${ }^{c}{ }^{\prime}$ al-Islam, he gives one of the most explicit expositions regarding the extent of the jurist's authority during the occultation. In his chapter on 'Enjoining Good and Forbidding Evil', he states that no one is allowed to enforce the prescribed Islamic punishments ( $h u d \bar{u} d$ ) except the infallible Imam or his appointee. ${ }^{73}$ However, he states, according to a great number of scholars, it is permissible for knowledgeable fuqaha $\bar{a}^{3}$ to implement the hudüd during the time of the occultation as it is their right to judge between people; furthermore, it is obligatory on people to help them towards this cause in the same way that it is obligatory for them to support the Imams. He attributes this view to a great number of scholars including Ibn Junayd al-Iskafi (d. before 377/987), the two Shaykhs (outstanding scholars) al-Mufid (d. 413/1022) and al-Tusi (d. 46o/1068), Sallar al-Daylami (d. 463/1071), ${ }^{74}$ Muhammad b. Makki (known as al-Shahid al-Awwal) (d. 786/1384), Zayn al-Din 'Amili (known as al-Shahid al-Thani) (d. 966/1559), Fadil Miqdad (d. 826/1423), Ibn Fahd al-Hilli (d. 841/1437), al-Karaki (d. 940/1533), Muhaqqiq Sabzavari (d. 1090/1679), and Fayd al-Kashani (d. 1090/1679). ${ }^{75}$

Al-Najafi argues that not only is this authority confirmed with regard to the implementation of hududd, it also goes beyond that and covers all remits of the Imam's authority ${ }^{76}$ for 'if the wilāya was not all-encompassing a great number of issues related to Shi' is would have remained unattended to. ${ }^{77}$ In other words, he believes that the faqi $h$ 's social status during the time of occultation is the same as that of the infallible Imam. He claims that the verdict of Shici fuqah $\bar{a}^{2}$ on this matter is unanimous, since in their works, they frequently underscore the idea of referring to a ha kim who is the agent and the representative of the absent Imam. ${ }^{78}$ Faced with all this evidence, he argues, those who hesitate on this matter 'have not tasted the flavour of fiqh [Islamic law] and have not understood in the least the undertone of their (the Imams') words and their ciphers. ${ }^{79}$

The same views were independently developed by his senior contemporary Mulla Ahmad Naraqi (d. 1245/1829), mainly in his famous work 'Awa'id al-Ayyam (Earnings of the Life Days) ${ }^{80} \mathrm{He}$ dedicates a whole chapter (' ${ }^{3}$ 'ida, Earning) $)^{81}$ to the issue of wilayat al-hākim, the authority of the ruler. In the chapter, he takes the wilaya of the fuqah $\bar{a}^{\prime}$ for granted and sets himself the task of determining the extent of their wilaya. ${ }^{82} \mathrm{He}$ argues that not only does the wilaya of the just jurist extend to 'whatever the Prophet (peace be upon him and his family) and the Imams (peace be upon them), who were the rulers over the people and the fortresses of Islam, had authority over and whatever right belonged to them,' but also includes anything that the affairs of the people depend on, while there is no specific permission for anyone to attend to them. Like al-Najafi, he claims that the issue of al-wilāyat al-'ämma is consensual among Shici jurists. ${ }^{83}$ 
However, Shaykh Murtada Ansari, a student of both the above-mentioned scholars, did not accept that such a consensus existed, although he admits the popularity (being mashhür) of it among the scholars. ${ }^{84}$ Unlike his teachers, he believed that the extent of the wilaya for the jurist is very limited and is in effect restricted to issuing fatwas (legal opinions) and settling legal disputes. He famously wrote that it would be easier to prove pigs fly than to prove all-encompassing authority (al-wilāya al-'āmma) for the jurist!' 85

The contrasting approaches of Ansari and his teachers suggest that the matter was solely a theoretical dispute and not an idea prompted by political circumstances as Lambton claims about al-Karaki. In fact, the idea had a long history among the scholars of the school of Baghdad and dates back to the pre-Safavid scholars of Lebanon. Among the most prominent scholars of the school of Baghdad, Shaykh al-Mufid (d. 413/1022) believed that Shi'i fuqah $\bar{a}^{3}$ 'could gather their brethren for Friday and Eid prayer' but also, based on sound narrations that have reached us from the Imams, 'could assume all duties placed in the remit of judges in Islam because the Imams have left for them this authority if they are able to do it.' ${ }^{86}$

Such a belief, sometimes with more and sometimes less emphasis, was found among the majority of jurists as mentioned by al-Najafi. Even the mild Akhbari Fayd Kashani (d. 1091/1680) regards it as one of the necessary tenets of the faith and maintains that the authority of the "trusted fuqah $\bar{a}$ " is the same as the authority of the Imam except in calling for offensive jihad. This authority belongs to them, he says, based on 'the right of deputyship' (haqq al-niyāba). ${ }^{87}$ In this regard, Stewart takes on the 'misconception concerning the Shiite legal system [...] that the exclusive authority of Shiite jurists was not established until quite recently, even as late as the nineteenth century, as advocated by Arjomand in his Shadow of God. Stewart notes that since the late tenth century, in general, prominent Shici jurists held that they were 'the ones to take over the essential functions of the imam during the Occultation. ${ }^{88}$ It is therefore quite uninformed to attribute the theory of wilayat al-faqih to al-Karaki's or Khomeini's political agendas and to regard it as an anomaly in Shici jurisprudence.

However, Khomeini added something new to the theory which was not explicitly mentioned by his predecessors and which caused confusion and resistance among many of his contemporaries. ${ }^{89}$ All the jurists who believed in al-wiläya al-muțlaqa before him restricted it to political authority and practical implementation of the law. Khomeini broadened the scope of the authority to theoretical matters, as will be explained in due course. This was the new challenge of the times facing Islamic law, which Khomeini tried to tackle with the old theory of wilàya al-faqih.

\section{AYATOLLAH KHOMEINI AND REVISITING THE SCOPE OF AUTHORITY}

As no fundamental changes affected Shici society until the nineteenth century, Shici jurisprudence, like Sunni jurisprudence, did not develop during this time. However, the constant defeats against the invading Russians during the first and second Russo-Persian Wars in the nineteenth century deeply shook the Iranian society. Further, Nasir al-Din Shah Qajar (d. 1896) made many trips to the West and was impressed by their progress. The West also had a significant impact on the educated class and gave rise to an insatiable desire for a massive 
Westernisation project in areas such as military, economy, social life and politics, especially under the reign of Nasir al-Din Shah Qajar (d. 1896). The newly introduced changes posed great challenges to faithful Muslims who urged Shici scholars to address the situation, on the assumption that Islamic law is capable of addressing the changing necessities of the time.

Mirza Muhammad Husayn Naini (d. 1936), who was one of the most influential scholars of the nineteenth century, was the first to elucidate a compatibility between the modern constitutional system ${ }^{90}$ of government and the traditional Islamic legal and political system in his Tanbih al-Umma wa-Tanzih al-Milla (Awakening the Umma and Purifying the Creed). Na'ini's writings mostly aimed to respond to the traditional Shi'i scholars who opposed a legislating body or parliament, arguing that Islamic law can still operate in a parliamentary system. Naturally, his ideas were not well received, and traditional Shici scholars put up stiff resistance to it. Shaykh Fadl Allah Nuri was one of the most stringent opponents to the Constitutional Revolution. He mainly objected to the idea of a constitution on the grounds that it would infringe on Islamic law by delegating legislative authority to people, as opposed to God. ${ }^{91}$ Those who opposed a legislative body believed that, given the existence of Islamic law, a parliament would be redundant. In addition to other sources, the laws are divinely legislated through the Qur'an and sunna, and therefore establishing a parliament would take away the legislative power of God. They saw parliament as an innovation, the rulings of which were to be regarded as unlawful or harām.

In his response, Nåini, akin to Ahmet Cevdet Pasha's Mecelle and Rashid Rida, divided Islamic law into two types of rules: manșūṣ (expressed) and ghayr-i manșūṣ (unexpressed). The manșuss rules are those which are clearly expressed in the Qur'an and sunna and thus 'cannot be changed on a spatial-temporal basis and for which no other duty but obedience has been envisaged.' On the other hand, ghayr-i manșūṣ rules:

are affected by time and place and undergo compulsory changes. Even during the time of the Prophet (peace be upon him and his family) and the infallible Imams, the judicial issues that came up in various parts of the Islamic lands and were specific to the said areas and which did not fall into the purview of the 'expressed' rules depended on the discretion and judgment of the one who was appointed in the specific area by the Prophet (peace be upon him and his family) or Imam. Such type of rules during the occultation (ghayba) of the Imam undergo changes which are consistent with the period and place, and the discretion, of jurisprudents who are deputies of the last Imam (peace be upon him and his family) or those who are authorised by them to do so. These individuals can take into any consideration any type of time-fitting legal system, which is in accordance with social conditions or not in contradiction to the 'expressed' rules. ${ }^{92}$

By dividing Islamic rules into two categories, Naini tried to demonstrate that a parliament can rightfully legislate on issues that are not expressed in Islamic law. ${ }^{93}$ Rashid Rida's division of Islamic law into 'ibādāt and mu'ämalāt is not exactly the same but in terms of its implementation amounts to the same consequences. The rules that are clearly expressed in the Qur'an and sunna cannot be changed, while anything that is not mentioned in these two sources may change. 
Sayyid Muhammad Husayn Tabatabaii (d. 1982), who was a student of Nảini and celebrated for his Qur'anic commentary, al-Mizān, further elucidated his teacher's views. He divides Islamic laws into:

The laws which change in place with time and in tune with the progress of civilisations, and concern special status and conditions, and laws which are irrevocable and are related to the unchallenged essence of humanity, which is common between all human beings in all ages, all conditions and all environments. ${ }^{94}$

Such a division of Islamic law may seem to solve some of the problems that Islamic law faces in addressing the ever-changing needs of society, but it also prompts another important question: who has the authority to decide and implement these revocable rules? Both Naini and Tabatabải maintained that a ruler or one possessing al-wilāya al-' $\bar{a} m m a$ (general guardianship) has jurisdiction over the revocable rules. Having said that, according to Tabatabaii, the authority of the ruler (wali) is not more than the authority of the head of a family in his daily decision-making and is not related to the drastic structural and legal changes in society.

However, such an approach fails to reflect the intrinsic connection between the legal rulings and social structure. They also do not provide an explanation for the social changes affecting the areas which may fall within the scope of irrevocable rulings. The breakthrough comes with Ayatollah Murtada Mutahhari (d. 1979), ${ }^{95}$ one of the leading ideologues of the Iranian Revolution and a close associate and student of Khomeini. ${ }^{96}$ Mutahhari puts forward the following observation:

the problem with the issue of Islam and time exigencies is the problem of co-existence and coordination between two objects that are against each other in their natures. Of the two, one is fixed and irrevocable in nature, while the other is revocable, not fixed and fluid. Since Islamic decrees could not be abrogated, they are unchangeable and permanent, and since time exigencies or any other issue related to time, including human necessities and living conditions, are not fixed, it is but natural they undergo changes.

In such a case how can two things, one of which is fixed and permanent by its nature while the other is ever-changing by its nature, co-exist and coordinate with each other?"${ }^{97}$

His answer to the question is rather simple but difficult to come to terms with. Unlike the previous scholars, he breaks the barrier between the revocable and irrevocable rules of Islamic law. Mutahhari believes that Islam has a device within its legal system which ignites internal changes of its own without the need of any person to prompt them, and scholars' role is to discover those changes. ${ }^{98}$

He further maintains that Islamic laws are enacted as factual propositions, not actual propositions. That is to say, the rules are universal and do not address specific events. As a result, there is a possibility of contradiction between Islamic legal rulings in a specific case. For example, in general, it is forbidden for a Muslim to come into contact with somebody from the opposite sex who is non-mahram.$^{99}$ However, in a specific circumstance, coming 
into contact with the opposite sex becomes obligatory, as in the case of saving a drowning person. Another example may be that eating the meat of unlawful animals or unlawfully slaughtered animals is forbidden for Muslims. But under specific circumstances, such as if a person is starving to death, it becomes obligatory for the person to eat the otherwise unlawful meat.

In the event of such a contradiction, ${ }^{100}$ Islamic law orders believers to follow the ruling that trumps over another; meaning to follow the more important and ignore the less important. ${ }^{101}$ Therefore, Mutahhari believes that it is the jurist's responsibility to be fully aware of time and circumstances, to be able to differentiate minor and major important things at various times.

However, these discussions remained theoretical until the triumph of the Islamic Revolution in Iran in 1979, when the new state introduced Islamic law to regulate Iranian society. The challenge was great for Khomeini, the leader of the revolution, who was tasked with implementing static Islamic rules in the modernised Iranian society. As a solution, he revisited the theory of wilayat al-faqì with a new perspective. As we saw above, wilāyat al-faqìh was a deep-rooted concept in Shici jurisprudence and quite popular among prominent Shic $i$ jurists. It proposed the wide-ranging authority (wilāya) of the faqih as unspecified deputy $\left(n \bar{a}^{\jmath} i b\right)$ of the Imam. However, this authority was only to implement the law and not to make the law; what Khomeini added to the concept was widening the scope of authority to the area of legislation. And it was this addition that he emphasised by absolute authority, wilāyat muṭlaq. ${ }^{102}$

As opposed to a common misconception, absolute authority here does not mean an absolute or despotic form of government, but rather possessing authority - which the late Tabataba'i and Naini believed should be within the jurisdiction of the mujtahids - not in a limited mode, but rather in absolute terms. What Khomeini meant by wilayyat al-faqi $h^{103}$ is, in fact, the absolute authority to devise and make laws and regulations in accordance with social exigencies. In this regard, on 22 February 1988, Khomeini said:

Time and place are two key factors for $i j t i h \bar{a} d$. The issue which had a ruling in the past might urge a new ruling in the political, social and economic context of a new system. This means that with accurate identification of economic, social and political relations a subject, which has apparently not differed from its previous form, might really have turned to a new subject, which warrants a new ruling. ${ }^{104}$

It is clear from the above passage that Khomeini is concerned with the law itself rather than the implementation of it. This is the main shift from the traditional view regarding wiläyat al-faqìh. However, he does not see that as legislating against or outside sharica, but merely as ijtihad to find new rulings in the framework of sharica, rulings on subjects with no precedence. In a way, he tries to broaden the boundaries of sharica to include the rulings regarding new subjects rather than going beyond the borders of sharica.

With regard to the concept of wilayyat al-faqih, Khomeini lays great emphasis on the role of the just government under the faqih as the inheritor of the wilaya of the Prophet and Imams, and as finder and implementer of the law. As Calder observes, in Khomeini's thought, Islamic law can only be executed by a government, and thus it 'demands neces- 
sarily the formation of a government.' ${ }^{105}$ However, Calder's following statement indicates that he did not understand what Khomeini intended with his concept of wilayat al-faqì : 'Khumayni's radical attitude to Islamic law is perhaps best seen in his assumption that divine law represents an effective alternative to constitutionalism or republicanism, and that indeed it excludes these other forms of governmental organisations: divine law precludes human law. ${ }^{106}$ Even Naini , who died almost a half century before Khomeini, did not regard Islamic law an alternative to constitutionalism. In his book, Naini mentions an interesting anecdote that shows how deeply the scholars engaged with the issue. According to the story, Naini saw the deceased Ayatollah Mirza Husayn Tihrani in a dream and asked him how his honourable wali-yi 'așr (the twelfth Imam) had commented on his views regarding constitutionalism. The Imam, he says, had told him that constitutionalism was a new name for an old concept; it is like instructing a slave with dirty hands to wash his hands. Naini interpreted that to mean that that the slave is the king who has usurped the ruling position, and the dirt on his hands is additional usurpation which is removed by constitutionalism. ${ }^{107}$ Thus, both Naini and Khomeini considered constitutionalism a vital component of Islamic law; the stark opposition of Khomeini's view with Calder's interpretation needs no further explanation.

\section{CONTEMPORARY CRITICISM OF WILĀYAT AL-FAQĪH}

Since existing studies on the issue mostly focus on the political aspect of the concept, they fail to understand how the system of wilayat al-faqih grows out of a jurisprudential concept and evolves into a political theory. ${ }^{108}$ As noted in the introduction, Hallaq's Shari ${ }^{\top} a$ : Theory, Practice, Transformations ${ }^{109}$ is the only work that focuses exclusively on the jurisprudential aspect of the concept. While Hallaq relies on Muhammad Qasim Zaman's views to reach his judgment, ${ }^{110}$ Zaman appears to have a limited grasp of the jurisprudential aspect of the concept, instead of focusing largely on political authority.

Zaman refers to two statements of Khomeini with the ostensible intention of exposing his contradictory views; one is from 1970 when he was exiled to Najaf and the other from 1988 after the triumph of the Islamic Revolution. In the latter remark, Khomeini responds to remarks by Ayatollah Sayyid 'Ali Khamene'i (the present leader of Iran) which aimed to ease the reaction of traditional scholars to Khomeini's views on the authority of the new government system. Khomeini's view that an Islamic government has overriding authority and neither the revocable nor irrevocable rules are immune to the authority of absolute wilàya was difficult to swallow for traditional jurists, who believed that irrevocable rulings cannot be changed.

Khamene'i, president of Iran at the time, stated in a Friday sermon that 'what the Imam meant was the authority of government within the framework of the shari'a and the indubitable [or irrevocable rules]'. Khomeini immediately responded in a letter to Khamene'i:

You are mistaken if you do not believe that the government, which on the principle of absolute wiläyat was entrusted by Almighty God to Prophet Muhammad (peace be upon him and his family), enjoys precedence as an important divine commandment over all jurisprudence rules. 
The comments on my remarks do not at all conform with my view that the government has the authority within the framework of divine rules. If the powers of the government are limited to the framework of jurisprudential rules of Islam, then it should be said that divine government and absolute wilāyat entrusted by God to Prophet Muhammad (peace be upon him and his family) would be meaningless and devoid of any content. As a token of my remarks, I would like to refer to the consequences of such an issue to which no one can adhere. To cite an example, the case of broadening streets which requires the taking over of a house or part of it does not fall within the framework of jurisprudence rules. The military service and dispatch of forces to battlefronts, ban against hoarding - except in two or three cases - custom duties, taxes, coding and control of prices, measures against distribution of narcotic drugs, banning addiction in any form, other than alcoholic drinks (which are divinely prohibited), bearing of arms in any form, and hundreds of such cases, which fall within the realm of government authority, would be beyond state jurisdiction as per your remarks. What has been or is said results from lack of sufficient knowledge about absolute wilàyat. What has been said to the effect that with such authority issue[s] such as muzäre' $a$ (contract for the cultivation of leasing land) or muzäreba (limited partnership) would be forsaken, even if they are presumed to be so, I would like to state explicitly that they are among authorities of government. ${ }^{111}$

Zaman compared this statement with an earlier one in which Khomeini mentions that 'they [the jurists] must now allow the laws of Islam to remain in abeyance, or in their operation to be affected by either defects or excess. If a faqih wishes to punish an adulterer, he must give him one hundred lashes in the presence of people, in the exact manner that has been specified...' ${ }^{112}$ and spotted the apparent contradiction in Khomeini's thinking. Based on this comparison, Zaman argues that Khomeini initially believed that the scholars did not have the authority to bend Islamic rules, but when he assumed power, he changed his mind and asserted the view that Islamic law may be changed for the sake of ensuring the greater good.

Based on Zaman's treatment of the two statements, noticeable gaps in his understanding of the underlying principles of wiläyat al-faqih become apparent. Khomeini undoubtedly upholds in his theory the divinity of Islamic law, the essence of which cannot be altered. In the talk that he delivered in 1970, he was reinforcing the view that if a punishment is prescribed for an offence, it must be implemented in the specific manner stated in sharica. No person has the right to implement the law in excessive or deficient manners. Khomeini emphasised that in the process of ijtihad for understanding the laws of sharica, one must consider the differences between subjects which may seem similar at first glance, and not try to apply a law to a different subject than that which it is legislated to. Moreover, ijtihad must consider the conflict of laws and values and a faqi h with political authority must be able to decide which law or value would overrule another law or value at any time and place and enforce it. In his response in 1988, Khomeini referred to the aspect of wilayat al-faqih according to which the jurist has the authority to choose between a variety of laws applicable to a specific situation.

Hallaq, who is one of the most important contemporary scholars of Islamic law, appears to have subscribed to Zaman's arguments. Hallaq covers a wide variety of issues pertaining to Islamic law in this particular work, and thus perhaps did not have the opportunity to focus on wilāyat al-faqīh duly. Nevertheless, his arguments need to be scrutinised for the 
sake of academic debate and progress. Hallaq emphasises the unorthodoxy of Khomeini's theory in that it considers the law not as a goal but as a tool for achieving a larger purpose:

He [Khomeini] adopted the view, unknown - in its modernist political connotations - to pre-modern Islamic jurists of any strand, that 'Islam regards law as a tool, not as an end itself. Law is a tool and an instrument for the establishment of justice in the society, a means for man's intellectual and moral reform and its purification.' [Hallaq is quoting from Khomeini's Islam and Revolution] Qasim Zaman has argued that this doctrine, which granted the FaqihRuler absolute authority over and above the law, was precisely what the Sunnite ulama feared the most. For 'in the guise of upholding Islam the state might make it subservient to its own goals and ultimately absorb it within itself'. It is this 'guise,' representing no more than a thin veneer that marks the superficial difference between a self-declared secular state and self-declared Islamic state. The ulama as well as the Islamists - Sunnite and Shicite - have yet to discover that, in the final analysis, a state is a state. ${ }^{113}$

Zaman's influence on Hallaq becomes clear when we compare their comments on mașlaha. As noted above, ${ }^{114}$ when Hallaq discusses al-Shātibī's legal theory, he mentions the 'relative' nature of the concept of mașlaha, which is ostensibly akin to secular law-making. He then differentiates between them by stating that, in al-Shātibī's theory, benefit and harm are determined in accordance with the Islamic worldview of preparing believers for the hereafter, not for a secular public good:

Bringing individuals in line with the command of the law as prescribed by God, and curbing their personal desires and whims, are precisely the reasons for which the Sharīa was decreed. It follows, therefore, that any act resulting from a purely personal consideration and violating the letter and spirit of the law is utterly forbidden. ${ }^{115}$

But when it comes to wilayyat al-faqih, he hastily reaches the conclusion that Khomeini's theory operates no differently than that of a secular state. There are several points to address in Hallaq's arguments. First, as we have seen above, wilayyat al-faqì $h$ does not operate outside of Islamic jurisprudence, and thus the jurist is not 'above the law'. The theory makes use of the flexibility provided within Islamic law by opting for the most appropriate ruling in the instance of a conflict between Islamic rulings, while ensuring this is not done arbitrarily.

With regard to being in harmony with traditional Islamic law, wilayat al-faqih is more appropriate to be considered within this framework than mașlaha. The latter is more prone to stray outside of the framework of shari a, as mașlaha is designed to enact new rulings and in this process, legal boundaries may easily be strained. Further, since there is no clear guideline by which mașlaha may be implemented, it is difficult to contain within the boundaries of Islamic law. On the other hand, wiläyat al-faqih works in the framework of ijtihad and is to do with definitions, subjects of laws, and conflicts of rulings and values. It is a methodical procedure rather than an arbitrary choice.

The statement that this theory 'granted the Faqih-Ruler absolute authority over and above the law, [which] was precisely what the Sunnite ulama feared the most' is highly problematic. As noted above, there are several Sunni scholars who believe that mașlaha has 
overriding authority over the Qur'an. If mașlaḥa has the power to override the Qur'an, it means that the jurist defining the mașlaha has absolute authority. Moreover, if what Hallaq states is true, then every legislative body and individual, like members of a parliament, would be above the law, since they make new laws. A person or body is regarded as above the law if they are not subject to law, not because they can legislate new laws.

There has always been an element of human involvement in the process of legislation and there is no denying that, in Khomeini's theory, divine law is to be implemented by man. In the face of overwhelming societal changes, Khomeini devised a way to offer a solution from within Islamic law. However, it is an obvious fact that the laws of shari'a have always been decided by ijtihad which is a process involving man's judgment, understanding, and background. In this regard, Malcolm H. Kerr provides insight into the relationship between man and law:

But since the underlying premise of the definition of procedural sovereignty is that law exists as a positive order of rules, humanly contrived, interpreted, and applied, even the creation of its values-regardless of their psychological origin or religious worth-must be considered man-made. It is man who chose to derive their legal norms from religious revelations. In the positive sense, it makes no more sense to say that religiously based law is created than it does to say that purely secular law is created by inert and impersonal physical circumstances. Law as law is made by men, whatever their motivation. When, as in the case of Islam, the declared source of law is religious morality, that is, morality in the form in which they interpret it. ${ }^{116}$

This relation is also outlined clearly in a well-known excerpt from Murtada Mutahhari where he states that the fatwas of a countrydweller have a rustic flavour and the fatwas of a city-dweller have an urban flavour:

The work of a faqih and mujtahid is the deduction and derivation of the precepts [of the sharica]; but his knowledge and understanding of all things, in other words, his worldview, has a great influence on the decisions he makes [...] If someone compares the fatwas of the fuqah $\bar{a}$, with each other, and then pays attention to the individual circumstances and each of these scholars' ways of thinking about living problems, he will see how the mental environment of a faqi $h$ and the information he has concerning the outside world influence his legal rulings in such a way that the legal rulings of an Arab faqih have an Arabic flavor, those of an Iranian have an Iranian flavor, and those of a countrydweller have a rustic flavor as opposed to the urban feel of those of a city-dweller. ${ }^{17}$

However, as has been argued by J. N. D. Anderson, a general misconception pertaining to Islamic law has considered it a 'rigid and static'118 system that is predetermined by God, leaving no room for 'any doctrine of natural law, or for human positive law in any significant sense: instead, the whole Sharī'a is basically and essentially divine. ${ }^{119}$ In practice, Anderson asserts that 'this was not, in fact, wholly true, for the process of giving legal opinions and of applying the law to new situations has, of necessity, always continued, and the Shari ${ }^{\top} a$ has thus slowly responded to the major exigencies of life.' Another misconception Anderson points out is that 'in theory at least, it is not society and its needs which make the law, but 
the law which shapes society and to which men's needs must perforce be conformed.' ${ }^{120}$ He challenges this view, as he believes that society played a greater role in the shaping of Islamic law. ${ }^{121}$

Going back to Hallaq's criticism of the arbitrariness of the theory of wilayyat al-faqìh:

This vision of the state entirely comports with Khomeini's other pronouncements that, in the name of the state, the Faqīh-Ruler could suspend with impunity Sharī‘a rules, major and minor, if the 'country's' interests required to do so [citing Zaman's Ulama]. In this vision, institutionalized checks and balances, both Western and Islamic, are absent. Weber's bureaucratic rationality, which gives the state its juristic and corporate personality, has been abdicated by the Jurist-Ruler and perhaps the Council of Guardians, what is lawful and what is not. They appear to be the only ones who decide what the 'country's interest' is. At the same time, these powers of determining the law in the name of the state in no way reflect the tradition of the Shari $\bar{i}^{\mathrm{c}} \mathrm{a}$, wherein the conjoined effects of the stability of the law and its supremacy guarantee, as they in fact did, that the 'state' always operates under the rule of law. ${ }^{122}$

Anyone having the knowledge about how the legislative system works under wilayat al-faqih in Iran would realise how far from reality the above statement is. As mentioned above, Khomeini was of the view that sharica laws must be extended to modern unprecedented subjects. So not only did he not want to suspend shari'a laws, but he wanted to extend them to new areas. He believed that sharica must work in all times and places and the jurists, through ijtihad, must be able to understand the rulings of sharica for every age and era. However, this was not done individually in an ad hoc manner.

The system works as follows. The parliament may arrive at the conclusion that they need to legislate a new law which goes against the traditional sharica rulings. They have to be able to show that the new ruling is justified because it addresses a new context. Since all legislations should be approved by the Guardian Council (shürā-yi Nigahbān), the new legislation automatically goes to them for approval. The Guardian Council (GC) is responsible for making sure that the laws legislated in parliament do not contradict the shari'a laws. Naturally, in cases where traditional sharica rulings are contradicted by new legislations, the GC returns the legislation to the parliament for amendment. If two-thirds of the parliament members vote for the necessity of the new legislation despite the GC's objection, then the law is referred to the Expediency Council (shürā-yi tashkhiṣ-i maṣlihat). The Expediency Council (EC) is an advisory board appointed by the wali faqīh (currently Ayatollah Sayyid 'Ali Khamene'i) to advise him on certain issues including matters pertaining to legislations of the above kind. It is only after the EC advises the wali faqih that the new ruling is necessary despite its apparent opposition to the sharica that he looks into its sharica aspects. He needs to embark on a new ijtihad to verify if the subject of the new legislation is different from the subject of the traditional shari'a ruling, which would then warrant a new edict in the sharica.

The undertone of the above system is that the sharica is not a static system of law but rather a dynamic $(p \bar{u} y \bar{a})$ system which can provide laws and rulings for new subjects, new contexts, and new generations through the process of ijtihad. Moreover, it moves ijtihad away from its individualistic context to a more realistic and collective examination of mat- 
ters. Hallaq is under the impression that it is the Council of Guardians that has the final say in the law making process; however, as we saw above, it is the Expediency Council that has the final say over disputed matters and shares the authority of the wilayat al-faqih. This is clearly stated in Dale F. Eickelman and James Piscatori's Muslim Politics. ${ }^{123}$ Eickelman and Piscatori, in their observation of the concept, point out the clash between the National Assembly and the Council of Guardians over many issues such as land reform, banking, taxation, and cultural issues. Therefore, Khomeini 'was eventually impelled to create a new institution, the High Council for the Discernment of Interests, which was ostensibly to act as his eyes and ears and resolve disagreement over fundamental issues that would endanger the revolution. ${ }^{124}$ He then delegated his absolute authority to the High Council for the Discernment of Interests to overcome 'the legislative impasse'. ${ }^{125}$

Therefore, it would be unwarranted to simply consider wiläyat al-faqìh as a 'guise' to exploit Islam for worldly goals. Rooted deeply in traditional Islamic jurisprudence, the concept aims to keep Islamic law in tune with the needs of society. Thus, the theory may be regarded as an evolution of Shici jurisprudence.

Before finalising the study, it may be pertinent to discuss briefly some of the prominent Iraqi scholars' objections to the theory of wilayat al-faqìh. As is well-expressed by Hamid Mavani, the majority of the Iraqi Shi'i scholars, including Ayatollah Abu al-Qasim al-Khu'i (d. 1992) and Ayatollah 'Ali al-Husayni al-Sistani, object the theory based on the lack of sufficient religious evidence. ${ }^{126}$ However, the significant change in the attitude of Ayatollah al-Sistani in the post-Saddam Iraq towards the scope of religious authority further reflects the intrinsic connection between social change and Islamic law. The Iraqi Shici community and scholars entered the modern period under Sunni dominant governments such as the Ottomans, the British Mandate, the Hashemite Kingdom of Iraq, and the Iraqi Republic; hence they were not pre-occupied with the same concerns as their Iranian peers. The Iraqi Shic $i$ community and scholars who endured a policy of oppression and subjugation, ${ }^{127}$ especially under the brutal rule of Saddam Hussein, were concerned more with their survival than attempting to respond to the necessities of social change. But when a pro-Shici government came to power after the removal of Saddam Hussein, in 2003, they played a more active role in the socio-political affairs of the country. In this vein, Harith Hasan Al-Qarawee's article 'The 'formal' Marja': Shi'i clerical authority and the state in post-2003 Iraq' is a critical testimony to how the Shici scholars of Iraq quickly adapted to the major shifts in post-Saddam Iraq through expanding the scope of their religious and political authority:

Nonetheless, Sistani's extraconstitutional role cannot go unnoticed. This role was symbolically recognized in the prologue of the Iraqi constitution which was drafted and took effect in 2005 , by denoting the guidance of 'the religious leadership... and the great marajic [plural for marjac]...' as a motive for writing the constitution and voting for the Transitional National Assembly (T.N.A.) that wrote it. Thus, the Grand Marjac, an informal entity, was cited as a source of legitimacy and a welcomed influence by formal entities. Beyond symbolic gestures, Sistani's office, directed by his influential son, Muhammed Reza, played a key role in forming the United Iraqi Alliance (U.I.A.), a Shici coalition dominated by Islamist factions. The U.I.A. became the largest parliamentary bloc in the T.N.A., hence giving Shici Islamists a leading position in the constitution-writing process. Moreover, two of Sistani's religious representa- 
tives, Ahmed As-Safi and Ali Abdul Hakim As-Safi, were elected as members in the T.N.A., probably to ensure that the marja ${ }^{c}$ could closely monitor the constitutional process. After all, Sistani and senior Shic $i$ ' ulama did not have much faith in political parties and their intentions.

Nor did they fully trust the American promise not to interfere in the constitutional drafting. ${ }^{128}$

As Mutahhari articulated above, the social circumstances in which scholars live play an important role in their religious views, and the Iraqi Shi'i scholars' changing attitude towards the scope of religious authority is yet another example of this reality.

\section{CONCLUSION}

In sum, there is an intrinsic connection between Islamic law and society. Islamic law becomes relevant to society to the extent that it is able to address the ever-changing exigencies of the times. But from the perspective of a traditional approach to Islamic law, it is difficult to keep up with the needs of society, especially in modern times. Therefore, both Sunni and Shici scholars have tried to come up with new theories to address the problem, and the theory of wiläyat al-faqìh is one of these methods. We have also noted that wilayyat al-faqīh and the Sunni legal notion of mașlaḥa are strikingly similar concepts, but wiläyat al-faqìh is more structured as it provides a procedure for more orderly and methodical implementation than mașlaḥ̄.

Wilāyat al-faqih is a deep-rooted concept in Shici jurisprudence and quite popular among prominent Shici jurists. Khomeini only expanded the scope of the authority to the area of legislation. Its implication is that the sharica is not a static system of law but rather a dynamic system which can provide laws and rulings for new subjects, new contexts, and new generations through the process of ijtihad. Further, it moves ijtihad away from its individualistic context to a more realistic and collective examination of matters.

However, due to a lack of research carried out with an open mind, as opposed to preconceived convictions, almost four decades after the introduction of the theory, it still remains to be understood properly. There is a need for more research on Shici legal theory and the theory of wilayyat al-faqi h, and these studies should be divorced from the emphasis on politics and/or ideology as such focuses have been a thick barrier that prevented scholars from understanding the development of Shici jurisprudence duly.

\section{NOTES}

1. We would like to thank the anonymous reviewers for their suggestions, criticism and comments, and Aaron Varricchio and David Coolidge for editing the article.

2. Bruce O. Riedel in Iran and The West 1/3: The Man Who Changed the World. Directed by Dai Richard. [England]: BBC, 2009.

3. Some of these works are: Nikki R. Keddie, ed., Religion and Politics in Iran: Shi ism from Quietism to Revolution (New Haven and London: Yale University Press, 1983); Nikki R. Keddie, Iran and the Muslim: Revolution and Resistance (New York: NYU Press, 1995); Norman Calder, 'Accommodation and Revolution 
in Imami Shi'i Jurisprudence: Khumayni and the Classical Tradition', Middle Eastern Studies 18, no. 1 (1982): 3-20; Dale F. Eickelman and James Piscatori, Muslim Politics (Princeton, New Jersey: Princeton University Press, 1996); Chibli Mallat, The Renewal of Islamic Law: Muhammad Baqer As-Sadr, Najaf and the Shi'i International (Cambridge: Cambridge University Press, 2003); Said Amir Arjomand, 'Authority in Shiism and Constitutional Developments in the Islamic Republic of Iran', in The Twelver Shia in Modern Times: Religious Culture \& Political History, ed. Rainer Brunner and Werner Ende, Social, Economic, and Political Studies of the Middle East and Asia, vol. 72 (Leiden and Boston: Brill, 2001), 302-32; Olivier Roy, 'The Crisis of Religious Legitimacy in Iran', Middle East Journal 53, no. 2 (1999): 201-16; Eric Hooglund and William Royce, 'The Shi'i Clergy of Iran and the Conception of an Islamic State', State, Culture, and Society 1, no. 3 (1985): 102-17.

4. Norman Calder, 'The Structure of Authority in Imami Shi'i Jurisprudence' (PhD, School of Oriental and African Studies (University of London), 1980).

5. Ibid., $171-72$ and passim.

6. Robert Gleave's Inevitable Doubt: Two Theories of Shï $i$ furisprudence (Leiden: Brill, 20oo) is another notable study on Shici legal theory.

7. Ann K. S. Lambton, State and Government in Medieval Islam: An Introduction to the Study of Islamic Political Theory: The furists, London Oriental Series, vol. 36 (Oxford: Oxford University Press, 1985), 242-87.

8. For earlier studies on Shi'i jurisprudence, see Joseph Eliash, 'The Ithnā'asharī-Shì'̄ Juristic Theory of Political and Legal Authority,' Studia Islamica, no. 29 (1 January 1969), 17-30; A. A. A. Fyzee, 'Shīî̀ Legal Theories', in Law in the Middle East, ed. Majid Khadduri and Herbert J. Liebesny, vol. 1 (Washington: The Middle East Institute, 1955), 113-31.

9. Said Amir Arjomand, The Shadow of God and the Hidden Imam (Chicago and London: The University of Chicago Press, 1984).

10. Hamid Algar, Religion and State in Iran 1785-1906: The Role of the Ulama in the Qajar Period (Berkeley and Los Angeles: University of California Press, 1969), 1-25.

11. Arjomand, The Shadow of God and the Hidden Imam, Chapter Ten.

12. Ibid., 231-32.

13. Abdulaziz Abdulhussein Sachedina, The fust Ruler in Shīite Islam (New York and Oxford: Oxford University Press, 1988).

14. Andrew J. Newman, 'The Development of Political Significance of the Rationalist (Ușūīi) and Traditionalist (Akhbārī) Schools in Imāmī Shi'ī History from the Third/Ninth to the Tenth/Sixteenth Century A.D.' (PhD thesis, University of California, Los Angeles, 1986).

15. Devin J. Stewart, Islamic Legal Orthodoxy: Twelver Shiite Responses to the Sunni Legal System (Salt Lake City: University of Utah Press, 1998).

16. Ibid., 252.

17. Shahrough Akhavi, 'Contending discourses in Shici law on the doctrine of Wilayat Al-faqih', Iranian Studies 29, no. 3-4 (1996): 229-268.

18. Hamid Mavani, 'Ayatullah Khomeini's Concept of Governance (wilayat al-faqih) and the Classical Shi' $\mathrm{i}$ Doctrine of Imamate,' Middle Eastern Studies, 47:5 (2011), 807-824.

19. Noel James Coulson, A History of Islamic Law (Edinburgh: Edinburgh University Press, 2001), 85. 20.A lucid example of the consequences of incongruousness between the society and Islamic law can be seen in the example of Hanafi $q \bar{a} \bar{d} \bar{l}$ Isma ${ }^{c} i l$ b. al-Yasa ${ }^{c}$. Ibn al-Yasa ${ }^{c}$ was the first Hanafi $q \bar{a} d \bar{l}$ to implement Hanafi law in Egypt, but his eagerness to apply 'unfamiliar and alien' rules in accordance with the teachings of the Hanafi school caused public resentment and he was soon dismissed from his duty in 166/783 (Noel James Coulson, A History of Islamic Law, 87.) 
21. See Ibid., Chapter Three.

22. Wael Hallaq, A History of Islamic Legal Theories: An Introduction to Sunni Ușül Al-Fiqh (Cambridge: Cambridge University Press, 1997), 2.

23. The authors do not intend to make a value judgement; rather they wish to emphasise how the advent of Islam caused dramatic changes in the once dormant Arabian society.

24. An individual who is qualified to derive religious rulings from the Islamic sources.

25. Noel Coulson, A History of Islamic Law, 80-81.

26. Bernard Weiss, 'Interpretation in Islamic Law: The Theory of Ijtihād,' The American fournal of Comparative Law 26, no. 2 (1978): 273; James P. Piscatori, Islam in a World of Nation-States (Cambridge: Cambridge University Press, 1986), 6.

27. Wael Hallaq, 'Was the Gate of Ijtihad Closed?', International fournal of Middle East Studies 16, no. 1 (1984), 3-41.

28. Ibid., 32.

29. There were other attempts to remedy the situation such as those of the secularist and nationalist movements, and Wahhabism (See Hallaq, A History of Islamic Legal Theories, 213).

30. Malcolm H. Kerr, Islamic Reform: The Political and Legal Theories of Muhammad 'Abduh and Rashìd Rid̄a (Berkeley and Los Angeles: University of California Press, 1966), 1.

31. James Piscatori, Islam in a World of Nation-States, 4.

32. Stanford J. Shaw and Ezel Kural Shaw, History of the Ottoman Empire and Modern Turkey, vol. 2 (Cambridge: Cambridge University Press, 1997), 65-66.

33. Ahmet Cevdet Paşa, Mecelle-i Ahkâm-i Adliye (Istanbul: Matb. Osmaniye, 1884), 24.

34. Ibid., 26.

35. Hamid Enayat, Modern Islamic Political Thought (London and Basingstoke: The Macmillan Press, 1982), 79. 36. Ibid.

37. Ibid.; cf. Oussama Arabi, Studies in Modern Islamic Law and Jurisprudence (The Hague, London, and New York: Kluwer Law International, 2001), 19-38.

38. Wael Hallaq, 'Was the Gate of Ijtihad Closed?', 219.

39. Felicitas Opwis, 'Mașlaḥa in Contemporary Islamic Legal Theory,' Islamic Law and Society 12, no. 2 (2005), 188.

40.Hossein Tabataba'i Modarressi, An Introduction to Shī̄i Law: A Bibliographical Study (London: Ithaca Press, 1984), 24 .

41. On the activities of Shici jurists and community in Baghdad during the Buwayhid, era see Stewart, Islamic Legal Orthodoxy: Twelver Shiite Responses to the Sunni Legal System, 118-25. Devin Stewart does not accept the validity of such an argument. Instead he proposes that despite the fact that Shicis managed to establish political dominance over their Sunni opponents during the Buwayhids and Safavids, they were still aware of their minority status in the face of the potentially hostile Sunni environment; thus the religious views of Shi is, both laymen and scholars, were a product of their conflict with the Sunni majority (Ibid., 22). As we have noted earlier, such an argument is highly problematic as it simplifies the development of sophisticated Shici legal theory and diminishes it to a reactionary movement.

42. Stewart again sees this development from the perspective that the rise of Buwayhids hegemony in Iraq and Iran resulted in Sunni insurgency and therefore led to more tension between Sunni and Shicis. Ibid., 54 .

43. Ibid.

44.Ibid., 115 .

JOURNAL OF THE CONTEMPORARY STUDY OF ISLAM | VOLUME 1 | ISSUE 1 | 2020

Seyfeddin Kara, Mohammad Saeed Bahmanpour • The Legal Authority of the Jurist and its Scope in Modern Iran • pages $1-27 \cdot$ DOI 10.37264/jcsi.v1i1.3 
45. Wilferd Madelung, 'The Spread of Maturidism and the Turks', in ACTAS Do IV Congresso de Estudos Arabes E Islamicos (Leiden: Brill, 1971), 156; cf. Arjomand, The Shadow of God and the Hidden Imam, 28-29. 46. Ahmad Kazemi Moussavi, Religious Authority in Shicite Islam (Kuala Lumpur: International Institute of Islamic Thought and Civilization, 1996), 29.

47. Ibid., 29-30.

48. Ibid., 30.

49. Arjomand, The Shadow of God and the Hidden Imam, 29; Stewart, Islamic Legal Orthodoxy: Twelver Shiite Responses to the Sunni Legal System, 72.

50. Andrew J. Newman, 'The Nature of the Akhbārī/Ușūlī Dispute in Late Șafawid Iran, Part 2: The Conflict Reassessed', Bulletin of the School of Oriental and African Studies 55, no. 2 (1992): 257-58.

51. Ann Lambton, State and Government in Medieval Islam, 268.

52. Ibid.

53. Harith Hasan Al-Qarawee's recent article studies a modern example of changing attitudes of Shici clergy to religious authority in the face of demanding socio-political context of post-Saddam Iraq. See Harith Hasan Al-Qarawee, 'The "formal" Marja': Shi'i clerical authority and the state in post-2ooz Iraq', British fournal of Middle Eastern Studies 46, no. 3 (2019): 481-497.

54. Newman, 'The Nature of the Akhbārī/Uṣūī Dispute in Late Ṣafawid Iran, Part 2: The Conflict Reassessed', 258.

55. Ann Lambton and Norman Calder interestingly argue that al-Shahīd al-Awwal (d. 786/1384) and al-Shahīd al-Thānī (d. 937/1530-1 or 940/1533-34) believed that during the absence of the Imam, Friday prayers were not obligatory. They maintain that al-Shahid al-Awwal opined that only Imams and their deputies can establish Friday prayers. Further, commenting on al-Shahid al-Awwal's opinion, al-Shahid al-Thani supported this view and argued that during the Occultation, a jurist is not allowed to carry out Friday prayers as the Imam appointed the jurist 'for a general purpose (manșūb min al-imām 'umūman), thus implying that he was not appointed specifically to hold the Friday prayers.' Having said that, Lambton notes, al-Shahid al-Thani (d. 937/1530-1 or 940/1533-34) acknowledges that 'in the ghayba there was a difference of opinion as to the obligatory nature of the Friday prayers' (Lambton, State and Government in Medieval Islam, 273; Norman Calder, 'The Structure of Authority in Imami Shi'i Jurisprudence,' 160-163). Conversely, al-Shahid al-Thani believed that Friday prayer was wajjib 'aynì (an obligation that is imposed on individual Muslims) during occultation (Zayn al-Din 'Alī al-'Amili, al-Rasa'il (Qum: Maktabat al-Basirati, n.d.), 51) and al-Shahid al-Awwal believed it was wājib takhyīrī (an optional obligation) (Muhammad b. Makki al-'Amili, al-Durus al-Shar'iyya fi Fiqh al-Imamiyya, vol. 1 (Qum: Daftar-e Intisharat-e Islami, 1997), 186).

56. Lambton does not state why she considers the two scholars enemies which renders her judgement unsubstantiated (Lambton, State and Government in Medieval Islam, 271).

57. Ibid., 273; Calder, 'The Structure of Authority in Imami Shi'i Jurisprudence,' 163-165.

58. Lambton, State and Government in Medieval Islam, 273.

59. See also Sachedina, The fust Ruler in Shi'ìte Islam, 235.

6o.Lambton, State and Government in Medieval Islam, 276.

61. Ibid.; cf. Norman Calder, 'The Structure of Authority in Imami Shi'i Jurisprudence,' 158-159.

62. Ann Lambton, State and Government in Medieval Islam, 276.

63. Norman Calder, 'The Structure of Authority in Imami Shi'i Jurisprudence,' 159.

64. Broadly, tacäruf is a system of courtesy that may involve exaggeratingly lowering the self in favour of the other. 
65. Andrew Newman does not dispute the authenticity of the farmān but based on its 'distinctive religious terminology' speculates that Karaki himself penned it. Andrew J. Newman, Safavid Iran: Rebirth of a Persian Empire (I. B. Tauris, 2009), 37.

66. The full text of the decree is included in Said Amir Arjomand, trans. and ed., 'Two Decrees of Shah Tahmasp Concerning Statecraft and the Authority of Shaykh Al-Karaki', in Authority and Political Culture in Shi'ism, ed. Said Amir Arjomand (Albany: State University of New York Press, 1988), 250-62.

67. Lambton, State and Government in Medieval Islam, 276-77.

68. Arjomand also considers it a reliable document. Arjomand, The Shadow of God and the Hidden Imam, 133-34.

69. See also, Akhavi, 'Contending discourses in Shici law,' Iranian Studies, 232.

70. The most detailed and precise study of these concepts can be found in Ahmad Vaezi, Shia Political Thought (London: Islamic Centre of England, 2004).

71. Joseph Eliash vehemently denies such an idea in Joseph Eliash, 'Misconceptions Regarding the Juridical Status of the Iranian "Ulama", International fournal of Middle East Studies 10, no. 1 (1979): 9-25.

72. Shaykh Muhammad Hasan al-Najafi, Jawahir al-Kalam fi Sharh Shara'i' al-Islam (Tehran: Dar al-Kutub al-Islamiyya, 1986), vol. 21, 394 .

73. al-Najafi, Jawahir, vol. 21, 386.

74. Sachedina, based on an indirect citation (he cites Khwansari's Rawdat, vol. 3, p. 91), argues that Sallar was against the assumption of the 'comprehensive authority' of the Imam (Sachedina, The fust Ruler in Shīite Islam, 12-13). However, in his original work reprinted in al-Yanabic al-Fiqhiyya, Sallar fervently supports the all-encompassing authority of the jurist (see 'Ali Asghar Marvarid, al-Yanabi' al-Fiqhiyya, vol. 9 (Dar al-Turath, 1990), 67.)

75. al-Najafi, Jawahir, vol. 21, 393-394.

76. Ibid., 396.

77. Ibid., 397.

78. Ibid., 396

79. Ibid., 397.

8o.Mulla Ahmad Naraqi, 'Awa'id al-Ayyam (Qum: Markaz al-Nashr, 1996).

81. Ibid., Chapter 54.

82. Naraqi, 'Awa'id al-Ayyam, 529.

83. Ibid., 536.

84. Shaykh Murtada Ansari, al-Makasib al-Muharrama (Qum: Majma' al-Fikr al-Islami, 20oo), vol. 3, 557.

85. Ibid., 546.

86. Shaykh Muhammad b. Muhammad b. Nưmān al-Mufīd, al-Muqnica (Qum: Mu'assasat al-Nashr al-Islami, 1990), 811.

87. Mulla Muhammad Muhsin Fayd Kashani, Mafatih al-Shara ${ }^{\dagger}$ ', vol. 2 (Qum: Majma'-i Dhakhåir-i Islami, 1981), 4-5.

88. Stewart, Islamic Legal Orthodoxy, 211.

89. For opposing views against Khomeini's theory, see Mavani, 'Ayatullah Khomeini's Concept of Governance,' Middle Eastern Studies, 807-824.

90.For a study of Na'ini's views on constitutionalism, see Amirhassan Boozari, Shi'i furisprudence and Constitution (New York: Palgrave Macmillan, 2011), Chapter Four.

91. Eickelman and Piscatori, Muslim Politics, 27. 
92. Muhammad Husayn Nåini, Tanbih al-Umma wa-Tanzih al-Milla (Qum: Daftar-i Tablighat-i Islami, 2003), 134 .

93. Akhavi provides a different interpretation of Na'ini's opinion on the matter. Akhavi, 'Contending discourses in Shici law,' 234 .

94. Muhammad Husayn Tabatabåi, Majmu'-i Maqalat va Pursish-ha va Pasukh-ha (Tehran: Daftar-i Nashr-i Farhang-i Islami, 1992), 70.

95. See J. G. J. Ter Haar, 'Murtazâ Mutaharî: An Introduction to His Life and Thought,' Persica 14 (1992 1990), $1-20$.

96. Ibid., 2 and passim.

97. Murtada Mutahhari, Islam va Muqtadiyat-i Zaman (Tehran: Intisharat-i Sadra, 1991), 11.

98. Ibid., 11.

99. Mahram is a close family member of the opposite gender, either biologically or through wedlock.

100. In other words, the contradiction occurs between al-hukm al-awwali (primary ruling) and al-hukm al-thānawi (secondary ruling). In the above example, coming into contact with someone of the opposite sex is a hukm awwali (primary ruling) and obligation to save human life is a hukm thānawì (secondary ruling). In the case of saving a drowning person, the secondary ruling trumps the primary ruling, and it becomes an obligation to save the person's life. However, Hamid Mavani's following remarks demonstrating how the concepts of al-hukm al-awwali and al-hukm al-thānawī operate within the concept wiläyat al-faqih are grossly misunderstood: 'Toward the end of his life, however, Khomeini stretched this concept to its farthest limit and expanded the scope of the jurisconsult's authority by proclaiming in January 1988 that this person is not confined to shari'a if it conflicts with the society's general welfare and best interests. Just what constitutes this general welfare and "imperative necessity," as well as how they are measured, remained undefined and vague. Moreover, the customary checks and balances over this person's expansive powers are conspicuously absent. With this proclamation, Khomeini elevated the state's preservation to a primary injunction [al-ahkām al-awwaliyya] and downgraded rituals (e.g., the obligatory prayers and fasting) to secondary injunctions [al-aḥkām al-thanāwiyya]. As a result, all governmental ordinances [ahkām al-ḥukumā'] became religiously binding $[w \bar{a} j i b]$ and their non-performance constituted a sin. In his own words: "I should state that the government, which is part of the absolute deputyship of the Prophet, is one of the primary injunctions of Islam and has priority over all other secondary injunctions, even prayers, fasting and hajj." Hamid Mavani, 'Khomeini's Concept of Governance of the Jurisconsult (Wilayat Al-Faqih) Revisited: The Aftermath of Iran's 2009 Presidential Election,' The Middle East fournal 67, no. 2 (2013), 209.

101. See Muhammad Rida Muzaffar, Usul al-Fiqh (Qum: Daftar-i Tablighat-i Islami, 1991), vol. 1, 299.

102. Mavani takes on Khomeini's religious proofs concerning absolute authority in Hamid Mavani, 'Analysis of Khomeini's Proofs for Al-Wilaya Al-Mutlaqa (Comprehensive Authority) of the Jurist', in The Most Learned of the Shi' a: The Institution of the Marja' Taqlid, ed. Linda S. Walbridge (Oxford University Press, 2001), 183-201.

103. Chibli Mallat mentions Ayatollah Baqir al-Sadr's alleged influence on Ayatollah Khomeini in the making of the theory of wilayyat al-faqih (Chibli Mallat, The Renewal of Islamic Law: Muhammad Baqer As-Sadr, Najaf and the Shi'i International (Cambridge: Cambridge University Press, 2003), 7 and passim) but such an assertion is unsubstantiated. The difference between Baqir al-Sadr and Khomeini is too great to go unnoticed. The former takes a more traditional approach and does not consider the jurist to have absolute authority, while for Ayatollah Khomeini, the jurist possesses absolute authority.

104. M. S. Bahmanpour, 'Introduction', in Muslim Identity in the 21st Century: Challenges of Modernity (London: Bookextra1998), 15. 
105. Calder, 'Accommodation and Revolution in Imami Shi'i Jurisprudence,' 11.

106. Ibid., 13.

107. Naini, 78-79.

108. Hamid Mavani again mistakenly assumes that the concept first grew as a political concept and was then expanded to be utilised as a jurisprudential concept. Hamid Mavani, 'Ayatullah Khomeini's Concept of Governance (wilayat al-faqih) and the Classical Shici Doctrine of Imamate,' 808.

109. Hallaq, Sharī ${ }^{\top}$.

110. Muhammad Qasim Zaman, The Ulama in Contemporary Islam: Custodians of Change, Princeton Studies in Muslim Politics (Princeton and Oxford: Princeton University Press, 2002), 105-107.

111. Bahmanpour, 'Introduction,' 17-18.

112. Zaman, The Ulama in Contemporary Islam, 106.

113. Hallaq, Sharī ${ }^{-} a, 488-89$.

114. Hallaq, A History of Islamic Legal Theories, 170.

115. Ibid.

116. Kerr, Islamic Reform, 7 .

117. Murtada Mutahhari, The Principles of Ijtihad, trans. John Cooper <https:/www.al-islam.org/printpdf/ book/export/html/21866>. Original available at Murtada Mutahhari, Dah Guftar (n.p.: n.d.) <http://lib.eshia. ir/500o6/1/121>, 121-122.

118. J. N. D. Anderson, 'Law as a Social Force in Islamic Culture and History,' Bulletin of the School of Oriental and African Studies 20, no. 1/3 (1957), 15.

119. Ibid., 15.

120. Ibid., 17 .

121. Ibid., 17.

122. Hallaq, Sharī $a, 491$.

123. Eickelman and Piscatori, Muslim Politics.

124. Ibid., 20.

125. Ibid., 50; Arjomand, 'Authority in Shiism and Constitutional Developments in the Islamic Republic of Iran,' 310-312.

126. Hamid Mavani, "Ayatullah Khomeini's Concept of Governance," 810-812.

127. See, Yitzhak Nakash, The Shi' is of Iraq (Princeton: Princeton University Press, 1994)

128. Al-Qarawee, "The 'formal' Marja", 9-10. 